DOI: $10.33764 / 2687-041 X-2021-3-69-72$

\title{
ОСНОВНЫЕ ПРОБЛЕМЫ ВЕДЕНИЯ ЕГРН НА СОВРЕМЕННОМ ЭТАПЕ
}

\section{Светлана Александровна Ракова}

Сибирский государственный университет геосистем и технологий, 630108, Россия, г. Новосибирск, ул. Плахотного, 10, ассистент кафедры геоматики и инфраструктуры недвижимости, аспирант, тел. (953)789-83-53, e-mail: chernonozhkina_s.a@mail.ru

\section{Дмитрий Николаевич Раков}

Сибирский государственный университет геосистем и технологий, 630108, Россия, г. Новосибирск, ул. Плахотного, 10, ассистент кафедры геоматики и инфраструктуры недвижимости, ассистент кафедры кадастра и территориального планирования, тел. (913)769-74-50, e-mail: rd.bbla@gmail.com

\section{Нина Алексеевна Беляева}

Сибирский государственный университет геосистем и технологий, 630108, Россия, г. Новосибирск, ул. Плахотного, 10, обучающийся, тел. (913)795-73-56, e-mail: nin-bel1998@mail.ru

Описаны основные этапы развития Единого государственного реестра недвижимости и выявлены основные проблемы на современном этапе. В статье приведены описание, характеристика и основные вопросы, решаемые единым государственным реестром недвижимости. Показаны основные источники ведения Единого государственного реестра недвижимости. Описываются основные ошибки, возникающие при ведении Единого государственного реестра недвижимости, и причины их возникновения. Сделан вывод о влиянии кадастровых ошибок при ведении единого государственного реестра недвижимости на кадастровую деятельность. Описана важность своевременного обновления кадастровых сведений путем применения современного оборудования кадастровыми инженерами.

Ключевые слова: кадастр, ведение Единого государственного реестра недвижимости, проблемы Единого государственного реестра недвижимости, современный кадастр, кадастровая деятельность, кадастровый инженер, кадастровые ошибки

\section{MAIN PROBLEMS OF USRR MAINTENANCE AT THE MODERN STAGE}

\section{Svetlana A. Rakova}

Siberian State University of Geosystems and Technologies, 10, Plakhotnogo St., Novosibirsk, 630108, Russia, Assistant, Department of Geomatics and Real Estate Infrastructure, Ph. D. Student, phone: (953)789-83-53, e-mail: chernonozhkina_s.a@mail.ru

\section{Dmitry N. Rakov}

Siberian State University of Geosystems and Technologies, 10, Plakhotnogo St., Novosibirsk, 630108, Russia, Assistant, Department of Geomatics and Real Estate Infrastructure, Assistant, Department of Cadastre and Territorial Planning, phone: (913)769-74-50, e-mail: rd.bbla@gmail.com

\section{Nina A. Belyaeva}

Siberian State University of Geosystems and Technologies, 10, Plakhotnogo St., Novosibirsk, 630108, Russia, Student, phone: (913)795-73-56, e-mail: nin-bel1998@mail.ru 
The main stages of development of the Unified state register of real estate are described and the main problems at the present stage are identified. The article provides a description, characteristics and main issues addressed by the unified state register of real estate. The main sources of maintaining the Unified state register of real estate are shown. It describes the main errors that occur when maintaining the Unified state register of real estate, and the reasons for their occurrence. The conclusion is made about the impact of cadastral errors when maintaining the unified state register of real estate on cadastral activities. The importance of timely updating of cadastral information by using modern equipment by cadastral engineers is described.

Keywords: cadastre, maintenance of the Unified State Register of Real Estate, problems of the Unified State Register of Real Estate, modern cadastre, cadastral activities, cadastral engineer, cadastral errors

Кадастровый учет в современном виде появился в 90-х годах прошлого века в связи с появлением Роскадастра. Позднее сформировались государственный кадастр недвижимости (ГКН) и Единый государственный реестр права (ЕГРП). Каждая из структур отвечала за свои полномочия, допуская взаимное дублирование деятельности.

На современном этапе Единый государственный реестр недвижимости (ЕГРН) является единым хранилищем сведении об объектах недвижимости в Российской Федерации, которая объединяет в себе:

- Единый государственный реестр прав, сопровождающийся Федеральным законом «О государственной регистрации прав на недвижимое имущество и сделок с ним» от 21.07.1997 N 122-Ф3 [6];

- Государственный кадастр недвижимости, который сопровождается Федеральным законом «О кадастровой деятельности» от 24.07.2007 N 221-Ф3 [7].

Целью работы является рассмотреть проблемы ведения ЕГРН на современном этапе развития.

Несомненно, с введением ЕГРН упрощается ведение кадастровой деятельности, но не исключает проблемы в ее использовании, количество которых ежегодно увеличивается, что обуславливает необходимость и актуальность исследования.

Кадастровая система признается эффективной, когда процесс постановки на кадастровый учет происходит без активного участия граждан и юридических лиц, процесс межевания и кадастрового учета выполняется в сокращенные сроки, экономически выгодны и легки в исполнении. Несомненно, главную роль в ведении и контроле кадастровых отношений играет законодательство [4].

Единый государственный реестр недвижимости включает в себя:

1) реестр объектов недвижимости и состав вносимой в него информации;

2) реестр прав, ограничений и обременений, распространяющихся на недвижимое имущество и состав вносимой в него информации;

3) реестр сведений о границах, о береговых линиях, а также сведений о проектах межевания территорий и состав вносимой в него информации;

4) правила внесения информации в кадастр недвижимости, реестр прав на недвижимость и реестр границ [3]. 
Но введение ЕГРН не решает некоторые проблемы. В настоящее время одной из проблем являются кадастровые ошибки при ведении кадастровой деятельности можно заметить, что кадастровые ошибки никуда не делись и решать их все так же сложно.

Федеральный закон «О государственной регистрации недвижимого имущества», который вступил в силу 2 января 2017 года, интерпретирует кадастровую ошибку как фальсификация фактической информации об объекте недвижимости, хранящееся в ЕГРН. В свою очередь можно выделить следующие причины возникновения кадастровых ошибок:

- возникшие в результате работы кадастрового инженера;

- опечатки и искажения в бумагах, необходимых для постановки на кадастровый учет, включая уведомления [5].

Так как кадастровая документация содержит в себе огромный объем информации, как текстовой, так и числовой, то ошибки не бывают идентичными.

Зачастую причинами возникновения кадастровых ошибок могут служить следующие причины:

- использование кадастровыми инженерами устаревшего и неисправного оборудования;

- координирование объектов недвижимости в разных системах координат, а не единой государственной системой, из-за этого возможность определения взаимного расположения объектов недвижимости становится невозможным;

- координирование объектов недвижимости картометрическим способом;

- некомпетентность работников и неумение обращаться с измерительными приборами [2].

Из вышесказанного следует, что одной из главных проблем в сфере ведения ЕГРН является отсутствие актуальных сведений об объектах недвижимости, содержащихся в единой информационной системе или несоответствующая информация об учтённых объектах недвижимости [1].

Применение современных фотограмметрических методов в работе кадастрового инженера в целях организации комплексных кадастровых работ, которые выполняются одновременно в отношении всех расположенных на территории одного кадастрового квартала или территориях нескольких смежных кадастровых кварталов объектов недвижимости, что будет способствовать уменьшению количества кадастровых ошибок в ЕГРН и своевременной актуализации картографического материала, кадастровых сведений об учтённом недвижимом имуществе и объектах нестоящих на государственном кадастровом учете.

\section{БИБЛИОГРАФИЧЕСКИЙ СПИСОК}

1. Актуальные проблемы в сфере реализации кадастровых отношений и возможные пути их решения [Электронный ресурс] - Режим доступа: https://dokipedia.ru/document/5208808.

2. Нетребина Ю.С., Потоцкий А.Н., Батищева Н.А., Проблемы ведения Единого государственного реестра недвижимости на территории российской федерации. 21 век: фундаментальная наука и технологии. Материалы XIV международной научно-практической конференции [Электронный ресурс] - Режим доступа: https:/www.elibrary.ru/item.asp?id=32440554. 
3. Приказ Министерства экономического развития РФ от 16 декабря 2015 г. N 943 "Об установлении порядка ведения Единого государственного реестра недвижимости, формы специальной регистрационной надписи на документе, выражающем содержание сделки, состава сведений, включаемых в специальную регистрационную надпись на документе, выражающем содержание сделки, и требований к ее заполнению, а также требований к формату специальной регистрационной надписи на документе, выражающем содержание сделки, в электронной форме, порядка изменения в Едином государственном реестре недвижимости сведений о местоположении границ земельного участка при исправлении реестровой ошибки" (с изменениями и дополнениями) [Электронный ресурс] - Режим доступа: https://base.garant.ru/71363112/.

4. Современные проблемы Российского кадастра [Электронный ресурс] - Режим доступа: http://znakka4estva.ru/dokumenty/geodeziya-i-geologiya/sovremennye-problemy-rossiyskogokadastra/.

5. Федеральный закон "О государственной регистрации недвижимости" от 13.07.2015 N 218Ф3 [Электронный 1 ресурс] http://www.consultant.ru/document/cons_doc_LAW_182661/.

6. Федеральный закон "О государственной регистрации прав на недвижимое имущество и сделок с ним" от 21.07.1997 N 122-Ф3 [Электронный ресурс] - Режим доступа: http://www.consultant.ru/document/cons_doc_LAW_15287.

7. Федеральный закон "О кадастровой деятельности" от 24.07.2007 N 221-Ф3 (последняя редакция) [Электронный ресурс] - Режим доступа: http://www.consultant.ru/ document/cons_ doc_LAW_70088.

(C) С. А. Ракова, Д. Н. Раков, Н. А. Беляева, 2021 